\title{
DIODONOPSIS RAMIROMEDINAE (ORCHIDACEAE: PLEUROTHALLIDINAE), A NEW SPECIES FROM COLOMBIA
}

\author{
Lisa Thoerle ${ }^{1,3} \&$ Ramiro Medina Trejo ${ }^{2}$ \\ ${ }^{1} 23$ John Dyer Rd, Little Compton, Rhode Island, USA. \\ ${ }^{2}$ Sibundoy Valley, Alto Putumayo, Colombia \\ ${ }^{3}$ Author for correspondence: 1thoerle@cox.net
}

\begin{abstract}
A new species, Diodonopsis ramiromedinae, is described, illustrated, and compared with similar species. A brief history of Masdevallia sect. Pygmaeae and the genus Diodonopsis is provided. Diodonopsis ramiromedinae is most similar to $D$. anachaeta, but differs by sepals with apices acute or acuminate-triangular vs. narrowly caudate; longer petals with a descending, narrowly linear, rounded basal process vs. with an acute, retrorse basal process; and the larger lip, obovate with the apex very broadly rounded vs. oblong-subpandurate with the apex acute.
\end{abstract}

Key words: Colombia, Diodonopsis, Masdevallia, new species, Pleurothallidinae, section Pygmaeae

Introduction. When Carlyle Luer first turned his attentions to subdividing the large and untidy genus Masdevallia Ruiz \& Pav., he segregated five species into section Pygmaeae Luer (Luer 1986). At that time, he speculated that these species might not form a coherent group. In 2000, Luer established the subgenus Pygmaeia to accommodate several sections, including section Pygmaeae (Luer 2000a). When he treated the section in greater detail, Luer included only three species: $M$. erinacea Rchb.f., $M$. anachaeta Rchb.f., and M. pygmaea Kraenzl. (Luer 2000b).

Pridgeon and Chase (2001) transferred Luer's original five species of section Pygmaeae into a new genus, Diodonopsis Pridgeon \& M.W.Chase, but only molecular data of Masdevallia erinacea were included into the analysis. The placement of the species in Diodonopsis may change with more exhaustive molecular analysis (Oses \& Karremans, pers. comm. 2017).

The lip of Diodonopsis ramiromedinae Thoerle, the proposed species, is partitioned by oblique marginal folds and resembles that found in some members of Masdevallia section Alaticaules Kraenzl. However, the combination of the general habit, characteristics of the inflorescence, and the ornamented ovary support its placement in Diodonopsis.
TAXONOMIC TREATMENT

Diodonopsis ramiromedinae Thoerle, sp. nov.

TYPE: Colombia. Putumayo. Km 5 en nueva carretera o Variente San Francisco-Mocoa, márgen derecha río Putumayo, alt. $2600 \mathrm{~m}$, collected by R. Medina \& M. Suárez, 2 May 2012, and flowered in cultivation by R. Medina, 12 June 2017, R. Medina 98 (holotype: JAUM!). Fig. 1-2.

DiAgnosis: Diodonopsis ramiromedinae is most similar to $D$. anachaeta, but differs by sepals with apices acute or acuminate-triangular vs. narrowly caudate; longer petals with a descending, narrowly linear basal process vs. with an acute, retrorse basal process; and the larger lip, obovate and divided into two parts by marginal folds, the hypochile verrucose, the epichile subcircular with radiating lamellae, vs. oblong-subpandurate with the apex acute, and lacking lamellae.

Epiphytic, small, caespitose herb; roots $0.5 \mathrm{~mm}$ diam. Ramicaul erect to suberect, 3-5 mm long, enclosed by 2 membranous, loose basal sheaths. Leaf erect to suberect, coriaceous, petiolate, elliptic-obovate, apex subobtuse, minutely tri-apiculate, base narrowly cuneate into the petiole, $15-20 \times 3-5 \mathrm{~mm}$, including the petiole 5-7 $\mathrm{mm}$ long. Inflorescence erect, from low on the ramicaul, bearing a single flower and a filament 

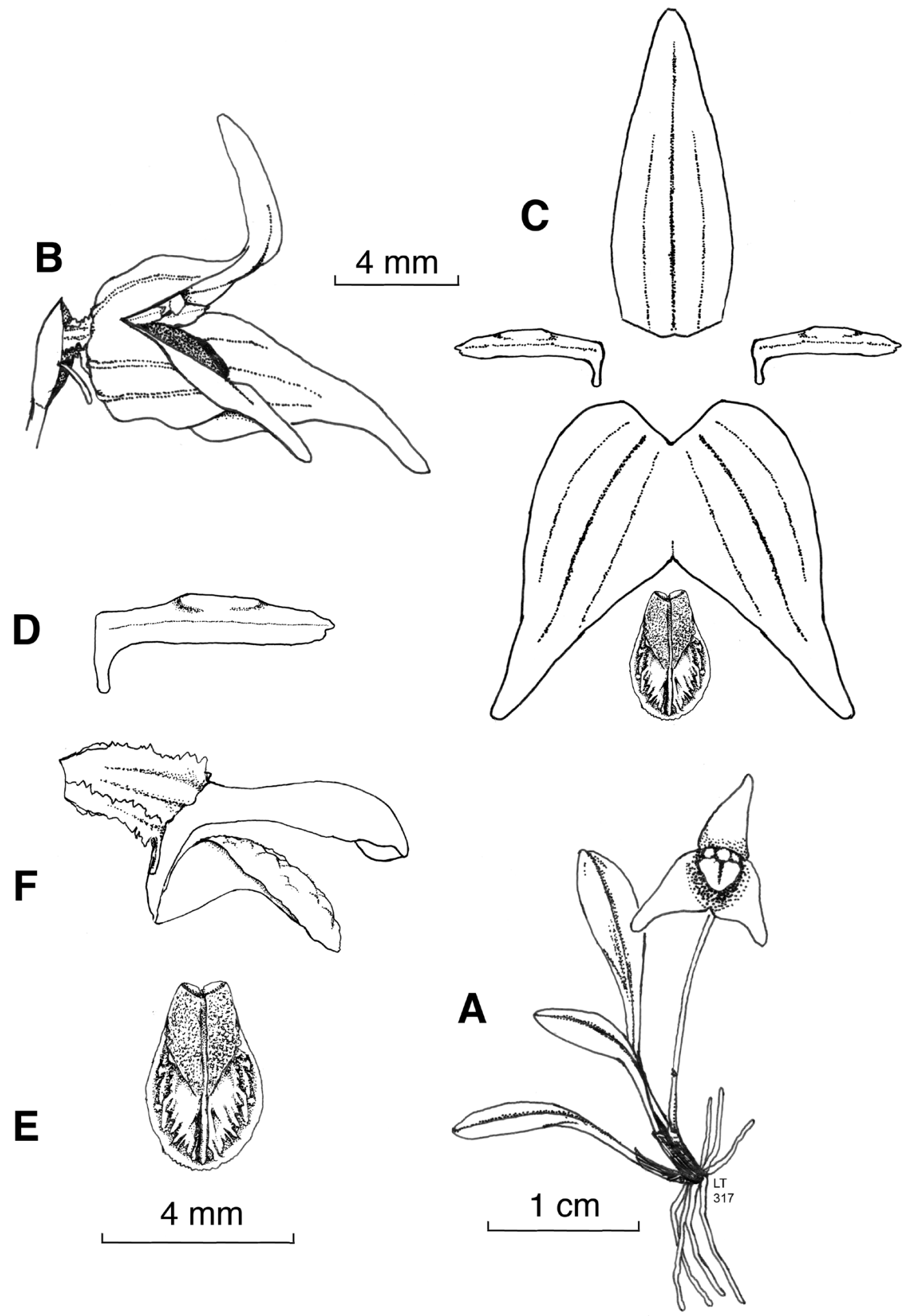

Figure 1. Diodonopsis ramiromedinae Thoerle. A. Plant habit. B. Flower. C. Dissected flower. D. Petal. E. Lip. F. Ovary, column, and lip. Drawn by L. Thoerle from the plant that provided the holotype. 


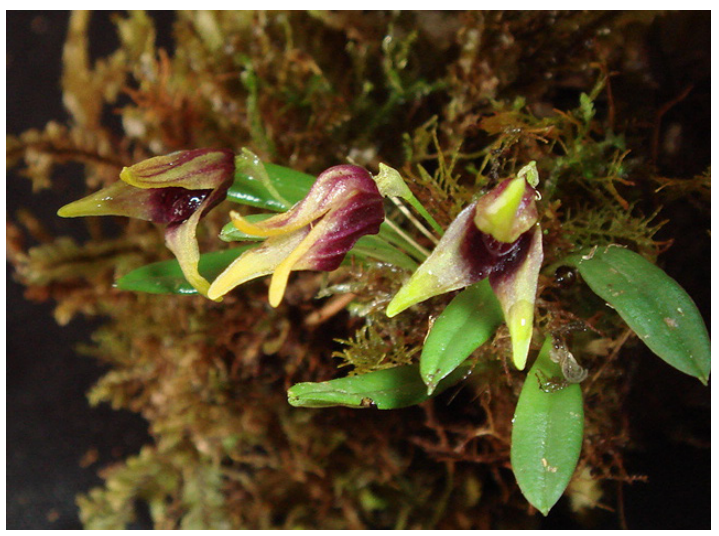

FIGURE 2. Diodonopsis ramiromedinae. Flowered in cultivation and photographed by R. Medina Trejo from the plant that provided the holotype.

representing a vestigial flower, 2-3 cm long including the terete peduncle 1.8-2.7 cm long; peduncular bract 1 , very small, low on the peduncle; floral bract cucullate, ovate-acuminate, 3-4 mm long; pedicel enveloped by floral bract, 2-3 mm long; ovary ca. $2 \mathrm{~mm}$ long, cristate with margins irregularly and coarsely dentate. Flower with sepaline tube ca. 4-5 mm long, free parts above gaping; sepals glabrous, entire, dull maroon at base, yellow toward apex, veins thickly carinate on the exterior; dorsal sepal ovate-elliptic, acute, with apex thickened, narrowly rounded, 10-12 × 4-5 mm, 3 -veined, connate to the lateral sepals for ca. $2.5 \mathrm{~mm}$ to form a sepaline tube, the free portion beyond the tube recurved, erect; lateral sepals ovate with apices short, thickened, acuminate, ends narrowly rounded, 10-12 $\times$ $5 \mathrm{~mm}$, connate $4 \mathrm{~mm}$; petals membranous, translucent pale yellow, narrowly oblong-linear with apex minutely erose, apiculate, with a small callus on the middle third of the upper half, the base with a narrowly linear, rounded, descending process $c a$. $1 \mathrm{~mm}$ long, appressed to the column-foot except for a small portion of the apex, blade $5 \times 1 \mathrm{~mm}$; lip dark red-purple, thickly coriaceous, obovate, with a deep sulcus, divided by oblique marginal folds extending to the middle of the lip into an epichile and hypochile, the hypochile verrucose, the epichile subcircular with minutely denticulate margins and raised, coarse lamellae radiating from the center nearly to the margin, the base truncate, hinged to the extension of the column-foot, $4.0 \times 2.5 \mathrm{~mm}$, 3-veined; column pale yellow suffused with purple at the apex, semiterete, $4.5 \mathrm{~mm}$ long, column-foot 2.25 $\mathrm{mm}$ long with a $0.3-\mathrm{mm}$ extension, anther and stigma ventral; anther cap pale cream, cucullate; pollinia 2, obpyriform.

DiSTRIBUTION AND HABITAT: Diodonopsis ramiromedinae is known from the type locality and an unspecified area in the eastern Sibundoy Valley, Colombia. The plant grows in humid forest, nestled in moss on thick, horizontal branches at a height of ca. $3 \mathrm{~m}$.

Eponymy: This species is named in honor of Ramiro Medina Trejo, one of the collectors and the cultivator of this plant, who specializes in the orchids of the Sibundoy Valley.

Phenology: Collected in flower in May; flowers in cultivation from March to May.

This species is most similar to the more common and widespread Diodonopsis anachaeta (Rchb.f.) Pridgeon \& M.W.Chase [三 Masdevallia anachaeta] (Fig. 3), but is readily distinguished by floral characteristics. The dorsal sepal of $D$. ramiromedinae is elliptic-ovate, with the apex acute, and the lateral sepals are $5 \mathrm{~mm}$ wide, with the short apices bluntly acuminate-triangular; the dorsal sepal of $D$. anachaeta is elliptic with a distinct cauda, and the lateral sepals are $3 \mathrm{~mm}$ wide, with narrow, caudate apices. The petals of $D$. ramiromedinae are 5 $\mathrm{mm}$ long with a descending, narrowly linear, rounded basal process appressed to the column-foot for most of its $c a$. 1-mm length; those of $D$. anachaeta are $2 \mathrm{~mm}$ long, with an acute, retrorse tooth that is less than 0.5 $\mathrm{mm}$ long and free of the column-foot. The lip of the new species is obovate with the apex very broadly rounded, $4.0 \times 2.5 \mathrm{~mm}$, divided in two parts by marginal folds that extend to about the middle of the lip, with the hypochile verrucose and the epichile with radiating lamellae. The lip of $D$. anachaeta is oblong-subpandurate with the apex acute, $2.5 \times 1 \mathrm{~mm}$, neither completely divided nor heavily textured.

The new species also superficially resembles Diodonopsis pygmaea (Rchb.f.) Pridgeon \& M.W.Chase [三 Masdevallia pygmaea] (Fig. 4), from which it is distinguished by vegetative and floral characteristics. The leaves of $D$. ramiromedinae are elliptic-obovate, 3-5 mm wide; those of D. pygmaea are narrowly linear, 1-2 $\mathrm{mm}$ wide. Floral differences include the ovary, irregularly cristate vs. densely muriculate; lateral sepals with acuminate-triangular 


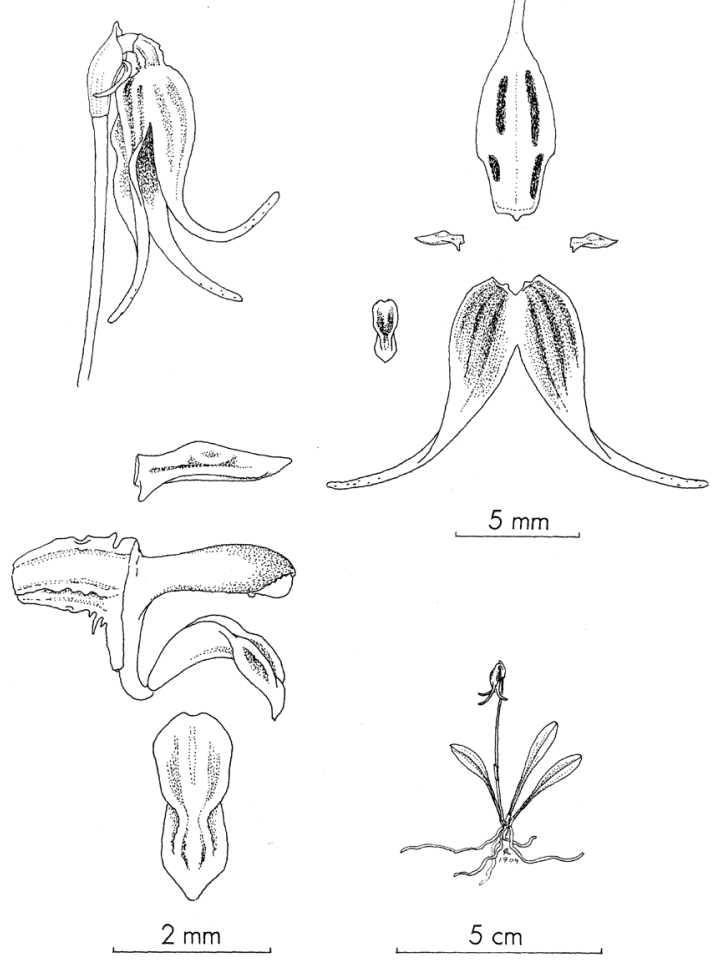

FIgURE 3. Diodonopsis anachaeta (Rchb.f.) Pridgeon \& M.W.Chase (as Masdevallia anachaeta Rchb.f.). Drawn by C. Luer, from Icones Pleurothallidinarum XXI, Systematics of Masdevallia: part two. Monographs in systematic botany from the Missouri Botanical Garden 82: 442 (2000). Reproduced with the kind permission of the Missouri Botanical Garden Press, St. Louis.

apices shorter than the blades vs. with well-developed caudae longer than the blades; petals $5 \mathrm{~mm}$ rather than $1.5 \mathrm{~mm}$ long; and the lip obovate and divided, $4 \mathrm{~mm}$ long vs. elliptic-oblong and undivided, $2-2.5 \mathrm{~mm}$ long.

Acknowledgments. This manuscript was prepared for the issue of Lankesteriana commemorating the $95^{\text {th }}$ birthday of Carlyle Luer, investigator of the Pleurothallidinae. We thank Adam Karremans of JBL for generously sharing his current research on the phylogenetics of the genus Masdevallia, two reviewers whose suggestions improved this paper, and JAUM for accepting the specimen under the amnesty for pre-2014 collected material. We are especially grateful to Carolina Medina, who supports our collaboration in more ways than we can enumerate.
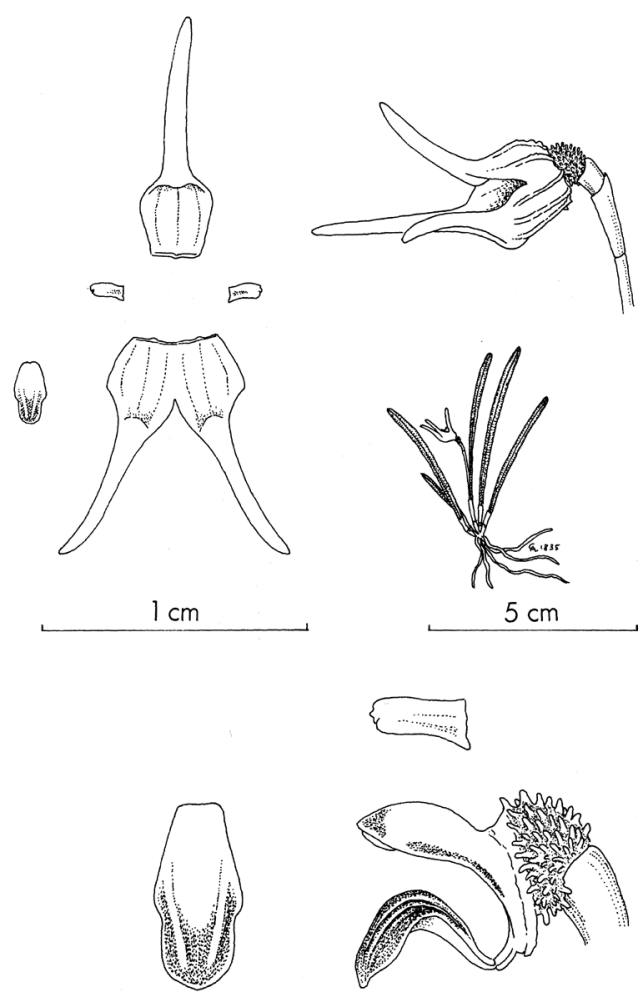

$2 \mathrm{~mm}$

Figure 4. Diodonopsis pygmaea (Rchb.f.) Pridgeon \& M.W.Chase (as Masdevallia pygmaea Rchb.f.). Drawn by C. Luer, from Icones Pleurothallidinarum XXI, Systematics of Masdevallia: part two. Monographs in systematic botany from the Missouri Botanical Garden 82: 488 (2000). Reproduced with the kind permission of the Missouri Botanical Garden Press, St. Louis.

\section{LiTERATURE CITED}

Luer, C. A. (1986). Icones Pleurothallidinarum 2, Systematics of Masdevallia (Orchidaceae). Monographs in systematic botany from the Missouri Botanical Garden, 16, 1-63.

Luer, C. A. (2000a). Icones Pleurothallidinarum 19, Systematics of Masdevallia: part one. Monographs in systematic botany from the Missouri Botanical Garden, $77,1-264$.

Luer, C. A. (2000b). Icones Pleurothallidinarum 21, Systematics of Masdevallia: part two. Monographs in systematic botany from the Missouri Botanical Garden, 82, 1-518.

Pridgeon, A.M. \& Chase, M.W., (2001). A phylogenetic reclassification of Pleurothallidinae (Orchidaceae). Lindleyana, 16(4), 235-271. 